\title{
Hvor socialistisk er den virkeliggjorte socialisme?
}

\author{
Peter Bundesen
}

\section{Indledning}

Hovedsigtet i det følgende er at diskutere nogle teorier om de kommunistpartistyrede landes sociale karakter. Som udgangspunkt argumenteres der for, at enhver forestilling om disse lande som »overgangssamfund « baserer sig på en socialismeforestilling, der dels ikke rækker ud over det borgerlige samfund og dels suggererer en historicistisk forståelse af disse samfund som »overlegne« eller »højere« i forhold til de vestlige kapitalistiske samfund. Det er således påstanden, at overgangsbegrebet blokerer for en forståelse af disse samfunds sociale karakter og reproducerer deres egen legitimationsideologi.

I forlængelse af denne kritik diskuteres det, om disse samfund kan begribes som en form for kapitalisme, eller om de må begribes indenfor en helt anden forståelsesramme. Denne problematik behandles ud fra spørgsmålet om landene skal forstås som henholdsvis »statskapitalistiske « eller »postkapitalistiske«. Her er det påstanden at postkapitalisme-opfattelsens begrundelse for, at man ikke kan betegne disse samfund som kapitalistiske baserer sig på en indsnævret kapitalismeforståelse, som begrænser sig til fordelingsforholdene og derfor ikke medreflekterer produktionsrelationernes kapitalistiske karakter. Derfor reproducerer også postkapitalisme-opfattelsen en forkortet kapitalismekritik.

Hovedsigtet med artiklen er således en gennemgang og kritik af teorier om disse samfundssystemer og kun som grundlag herfor inddrages egentlige analyser af de centrale reproduktionsformer i disse samfund.

\section{Kritik af overgangsforståelsen}

Indtil begyndelsen af tresserne havde den sovjet-docerede marxismeleninisme et tilnærmelsesvist ideologisk monopol på den vesteuropædiske venstrefløj. De fra dengang begyndende opløsningstendenser i dette »monopol « betød også en fornyet diskussion af den grundlæggende samfundskarakter i de lande, der styres gennem kommunistiske partier. Opfattelsen af disse lande som virkeliggjorte socialistiske på vej mod kommunisme blev mere og mere anfægtet. Idag er der kun få - udenfor kp-partierne som ikke vil mene, at den militære magtovertagelse i Polen, forfølgelsen af dissidenter, interventionen i Afghanistan etc. er i modsætning til socialisme. 
Imidlertid blev denne stigende politiske skepsis kun i begrænset omfang ledsaget af en egentlig teoretisk nyvurdering af disse landes sociale udvikling og karakter. Ganske vist er der i stadig stigende grad blevet stillet spørgsmålstegn ved om disse lande nu også kan betegnes som socialistiske, men også de problematiserende holdninger fastholder generelt en marxistisk-leninistisk forståelse af udviklingen, dvs. man også forsøger at forstå udviklingen indenfor en liniær evolutionistisk overgangsproblematik mellem kapitalisme og socialisme/kommunisme. ${ }^{1}$

Denne position har både en optimistisk og en pessimistisk variant. I den optimistiske forsikres det, at landene endnu ikke er overgået til socialisme, der findes endnu både kapitalistiske og socialistiske elementer, eller at der er tale om en fase efter kapitalismen, der endnu ikke er socialistisk. ${ }^{2}$ Imidlertid har den pessimistiske variant - som man også kan kalde den trotskistiske - været den mest udbredte på den vesteuropæiske venstrefløj. Indenfor denne påstås det, at der er sket en degenerering af sovjetsamfundet efter Oktoberrevolutionen. Opfattelsen af denne kan være mere eller mindre radikal.

I den forsigtige udgave - den ortodoxe trotskisme - betegnes sovjetunionen som en »degenereret arbejderstat «, hvorimod den radikale udgave går så vidt som til at påstå, at der ligefrem har fundet en rekapitalisering sted. Dette er opfattelsen hos den maoistisk orienterede kritik og den uortodoxe trotskisme. De mest kendte repræsentanter her er henholdsvis »mao-strukturalisten $«$ C. Bettelheim og T. Cliff. ${ }^{3}$

1. I den begrænsede danske behandling af disse samfunds karakter er denne overgangsproblematik også fremherskende. Se hertil temanummeret »Marxisme og de socialistiske lande« Historievidenskab nr 171979 og P. Neersø (red.), Sovjetunionens økonomiske system, S nr 61981.

Til trods for den altovervejende deskriptive tendens, kan man også spore denne opfattelse i skrifterne fra Øst- Vest-instituttet på SUC. Her skal der blot refereres til A. Jørgensens artikel »Krisen i Sovjetunionen og Østeuropa«. Han skriver: »Om Sovjetunionen rent faktisk er et socialistisk samfund eller ej, lader sig efter min opfattelse vanskeligt diskutere fra et videnskabeligt standpunkt. Det er snarere et spørgsmål om politisk præference. Det er givet, at privat ejendomsret til produktionsmidlerne er afskaffet, og det er klart, at produktionen søges udviklet efter en plan, som formodes bedst muligt at imødekomme befolkningens behov og udvikle landet på længere sigt. Det er efter min opfattelse også iøjnefaldende, at en række andre fænomener såsom indkomstudjævning, kulturel vækst, stigende social tryghed o.lign. peger i retning af en socialistisk økonomi. «Men da det også er klart, »at den sovjetiske virkelighed i øvrigt har meget lidt med klassiske marxistiske eller andre forestillinger om socialisme at gøre « beslutter han sig alligevel for, at »foretrække at tale om et ikke-kapitalistisk produktionssystem «. (A. Jørgensen, Krisen i Sovjetunionen og Østeuropa, i: J.J. Jensen (red.), Sovjetunionen i Forandring, Esbjerg 1980 ss. 171-172).

2. For en sådan opfattelse se P. Hennickes’ artikel i samme (red.) »Probleme des Sozialismus und der Übergangsgesellschaften«, Frankfurt/M 1973.

3. Jeg vil ikke her lave nogen enkeltgennemgang af disse positioner. For korte oversigter kan henvises til Historievidenskab nr 17 og til H. Olsens artikel »Teorier om Sovjetunionens samfundsmæssige karakter $« \mathrm{i}$ bogen $»$ Sovjetunionens $\emptyset$ konomiske system $«($ se note 1$)$. 
I det følgende vil jeg kritisere denne fastholdelse i overgangsproblematikken. Jeg vil argumentere for at anvendelsen af overgangsbegrebet er problematisk, og at den sociale struktur i disse lande kun ved anvendelse af et fordelingsteoretisk socialismebegreb meningsfuldt kan siges at være på vej til eller have været socialistiske.

Hvis overgangsbegrebet ikke skal udvandes til det meningsløse, må der kunne redegøres for hvilke samfundsmæssige modsætninger der bestemmer overgangen. Rakovski skriver herom; for at kunne placere et samfund som overgangssamfund må dets grundlæggende institutioner på en gang både forudsætte og udelukke hinanden, således at relationerne mellem samfundets magtcentre ikke er reguleret af mekanismer, der er accepteret som legitime af alle i samfundet, men af mere eller mindre åben klassekrig:

»For at kunne betegne sovjet-samfundene som overgangssamfund er det ikke tilstrækkeligt f.x. at pege på den samtidige tilstedeværelse af central planlægning, og noget der ligner det kapitalistiske marked. Det må også vises, at det første er inkarnationen af producenternes økonomiske magt, medens det sidste inkarnerer virksomhedsledernes magt, og at det legitime samarbejde mellem disse er uopnåeligt på langt sigt. Vi behøver blot at opstille problemet på denne måde for at kunne se, at overgangssamfundsbegrebet ikke kan anvendes på sovjet-samfundene.« (M. Rakovski, Marxism and the analysis of soviet societies, i Capital and Class nr 11977 s. 85.)

Det skal endvidere søges påvist, at overgangsforståelsen betjener sig af et fordelingsteoretisk socialismebegreb, der ikke adskiller sig principielt fra det socialismebegreb, der allerede er kendt fra de teoretiske positioner i den socialdemokratiske arbejderbevægelse og fra marxismen-leninismen selv. Hermed stiller »kritikken « sig grundlæggende på samme teoretiske position som de kritiserede og overser hermed, at en proletarisk social revolution er lige så påkrævet $\mathrm{i} \emptyset$ st som $\mathrm{i}$ vest.

I den fordelingsteoretiske socialismeforståelse opfattes klasseforholdene som blotte fordelingsforhold, hvorfor ejendom vs ikkeejendom til produktionsmidlerne bliver det afgørende kriterium for klassebestemmelsen. Derfor opfattes det afgørende kendetegn på ophævelse af kapitalismen ikke som ophævelse af kapital-lønarbejderforholdet - og hermed det fremmedbestemte lønarbejde -; men som afskaffelse af privatkapitalisternes ejendomsret over produktionsmidlerne, og indførelse af fordelingsformer, der ikke er bestemt af privatkapitalisternes »blinde « profitjagt, men af politiske beslutninger. I dette perspektiv drejer det sig således ikke om at afskaffe det fremmedbestemte lønarbejde, men om at ændre lønarbej- 
dernes levevilkår. Her overskrider socialismeforståelsen således ikke det borgerlige samfunds horisont.

Da det har været denne socialismeforståelse, der har været altdominerende indenfor såvel II som III Internationale og op til vore dages socialdemokratiske krav om ØD-socialisme, er kritikken af socialismeforståelsen i overgangssamfundsbegrebet samtidig også en kritik af den kapitalistiske arbejderbevægelses socialismeperspektiv.

Opfattelsen af de kp-styrede lande som overgangssamfund baserer sig på en opfattelse af Oktoberrevolutionen som en socialistisk revolution, eller i det mindste som et preludium til samme. Vi kan derfor nærme os en kritik af det fordelingsteoretiske socialismebegreb ved at se på bolsjevikkernes praksis og teoretiske overvejelser omkring Oktoberrevolutionen. Hensigten med denne gennemgang er at eftervise, at den »socialisme «, som de forestillede sig, ikke var en afskaffelse af lønarbejdet, men at deres forståelse lå indenfor det fordelingsteoretiske perspektiv. Det er denne amputerede socialismeforståelse, der også findes i vore dages opfattelse af samfundene som overgangssamfund, hvorfor enhver kritik, der baserer sig på en sådan forståelse, tiltrods for et ofte kritisk udgangspunkt, kun kan reproducere disse samfunds egne legitimeringsformer.

Bortset fra bøndernes allerede tidligere påbegyndte opdeling af storjordbesiddelserne i privatlodder - hvorved der etableredes en fremtidig trussel mod bolsjevikkernes magt - betød Oktoberrevolutionen ikke producenternes tilegnelse af produktionsmidlerne; men dens hovedresultat var derimod bolsjevikkernes - i rådenes navn - erobring af den politiske magt fra den provisoriske regering. Denne magterobring blev så anvendt til omfattende nationaliseringer af produktionsmidlerne. ${ }^{4} \mathrm{R}$. Rotermundt opsummerer resultatet i følgende paradox:

4. Imidlertid ville det være ganske uhistorisk at bebrejde bolsjevikkerne, at de ikke satte kapitalforholdets ophævelse på programmet, for som Rotermundt anfører: »Under de givne historisk-samfundsmæssige forudsætninger drejede det sig ikke desto mindre om det mest udviklede stade, som massebevidstheden overhovedet kunne antage. Den subjektive udvikling af et perspektiv for den kapitalistiske produktionsmådes ophævelse i socialisme forudsætter en udfoldet kapitalisme som grundlag, og ikke - som i Rusland - den isolerede gennemsættelse af lønforholdet i fabriksbyerne. Hvor kapitalforholdet ikke har gennemsat sig totalsamfundsmæssigt kan det heller ikke omstyrtes samfundsmæssigt. Man kan kun bekæmpe det objektivt i delområder og/eller bekæmpe det som Fabrikkens problem (i stedet for som fabrikssystemets problem). Hvor den samfundsmæssige udvikling har skabt denne slags forudsætninger, hvor lønarbejdekapitalforholdet ikke har udfoldet sig til det samfundsmæssigt bestemmende klasseforhold, hvorved der ikke er sket en samfundsmæssig integration af alle producenter, der kan ikke i det borgerlige samfund fremtræde de bevidsthedsudviklinger som er forudsætning for at den socialistiske bevægelse kan tænkes (altså erkendelsen af den menneskelige historie som menneskelig praksis, begribelsen af individet som samfundsmæssigt bestemt osv.); Der mangler proletariatet også grundlaget for at artikulere kravet om bevidst udformning af de samfundsmæssige forhold.« (R. Rotermundt, Oktoberrevolution und Sozialismus, i: Prokla nr 27, 1977 ss. 94-95.) 
»Det var den russiske revolutions paradox, at dér hvor produktionen virkelig blev overtaget af producenterne skete det på privat grundlag (...), men hvor privatejendommen blev ophævet skete den virkelige tilegnelse af produktionsprocessen ikke gennem producenterne, men gennem staten, $-\ll$ (R. Rotermundt op. cit. 101.)

I fortsættelse af nationaliseringerne gennemførtes en større eller mindre udskiftning af markedsprisreguleringerne med statslige plan- og reguleringsmekanismer for produktionsfordeling og forbrug. Oktoberrevolutionen resulterede således ikke i en ophævelse af producenternes underlæggelse i produktionsprocessen, men kun i en erstatning af kapitalens værdiøgningstvang med partistatens plan- og reguleringsmekanismer og overførsel fra privat ejendom til statsejendom.

Er forklaringen på dette begrænsede opgør med de kapitalistiske produktionsforhold, at bolsjevikkerne blev begrænset i deres sociale revolution eller svarer resultaterne også til deres socialismeforestillinger? Hvis vi henholder os til Lenins skriverier må det siges, at det sidste nærmest er det rigtige svar.

Lenin kritiserede primært kapitalismen for dens fordelingsforhold. ${ }^{5}$ Han opfattede kapitalismens grundlæggende modsætning som bestemt af forholdet mellem produktionens tiltagende samfundsmæssige karakter og den private tilegnelse af den. Denne modsætning løses kun ved, at der etableres tilsvarende samfundsmæssige tilegnelsesrelationer, og statsovertagelse opfattedes som en form for dette.

Indenfor en sådan forståelse angår kapitalismekritikken primært dennes muligheder for regulering af arbejdsfordelingen og af dennes produkter; men den kritiserer ikke kapitalismens adskillelse af produktion og behovsrealisering, en adskillelse der er formidlet gennem lønarbejdet. Hermed reduceres socialismeperspektivet til forbedring af lønarbejdernes arbejds- og levevilkår gennem ophævelse af privatejendommen til produktionsmidlerne og erstatning af den »anarkistiske« markedsregulering med en »bevidst « planmæssig regulering. Derimod har en kritik af lønarbejdet som udtryk for tvangen over producenterne i produktionen ingen plads i teorien.

Da Lenin forstod den historiske udvikling af produktivkræfternes samfundsmæssighed som lovmæssigt bestemt, forblev hans kapitalismekritik - foruden kritikken af dens uretfærdige fordeling - primært bun-

5. Dette afsnit støtter sig primært til U. Heidt og E. Mangeng, Parteivergesellschaftung, i: P.W. Schulze, Übergangsgesellschaft: Herrschaftsform und Praxis am Beispiel der Sowjetunion, Frankfurt/M 1974 og B. Rabel, W. Spon og U. Wolter, Halbheiten in der Überwindung des Leninismus, i: Prokla nr 11/12 1974. 
det til, at den som privat tilegnelsesform hæmmer produktivkræfternes udvikling. Socialismen skal så at sige ikke frigøre producenterne fra fremmedherredømmet, men sætte produktivkræfterne fri for begrænsede tilegnelsesformer.

Det fordelingsteoretiske socialismeperspektiv viser sig også i Lenins statsopfattelse. Han opfattede staten som dels et repressionsinstrument for det herskende borgerskab og dels som et $\varnothing$ konomisk administrativt samfundsmæssigt reguleringsinstrument. Det var revolutionens opgave at sønderslå det borgerlige herredømme over staten, hvorimod man også skal anvende dens $\varnothing$ konomisk-administrative potenser i den fremtidige samfundsregulering. Dog skal man i en overgangsperiode også anvende staten til undertrykkelse af borgerskabet. Det langtsigtede perspektiv var således den herredømmefri stat, men indtil da må den fungere som magtinstrument for den nye herskende klasse. Denne statsforståelse forklarer bolsjevikkernes prioritering af den politiske magtovertagelse. Det drejede sig om at erobre statsmagten, for hermed at forvandle den fra at være et herredømmeinstrument for borgerskabet til at blive et herredømmeinstrument imod dette.

For Lenin var det revolutionære subjekt ikke lønarbejderklassen, men det revolutionære avantgardeparti. Han havde overtaget Kautsky's forestilling om at lønarbejderne bevidsthedsmæssigt og organisatorisk umiddelbart begrænser sig til »trade-unionistiske « forestillinger og krav, hvorfor de ikke spontant vil angribe borgerskabets herredømme. Denne angivelige modsætning mellem grænserne for den faktiske bevidsthed i klassen og dens historiske mission søgte Lenin at løse med sit avantgardebegreb. Pga. sin organisatoriske og bevidsthedsmæssige begrænsethed kan klassens spontane kampe ikke overvinde kapitalismen. Avantgarden kan imidlertid pga. sin teoretiske skoling erkende de samfundsmæssige lovmæssigheder og de muligheder som klassens kampe har for at overvinde kapitalismen. Derfor er den i stand til at føre det socialistiske perspektiv ind i de tradeunionistiske massers ellers begrænsede kampe.

Opsummerende kan det fastslås, at spørgsmålet om overgang til kommunisme stillede sig således for Lenin: Pga. kapitalismens begrænsede tilegnelsesformer bliver det for produktivkræfternes fortsatte samfundsmæssige udfoldelse nødvendigt med tilsvarende samfundsmæssige tilegnelsesformer. Dette nødvendiggør imidlertid en politisk revolution, der ophæver privatkapitalisternes privatejendomsret og herredømme. Men da lønarbejderne umiddelbart er bundet ind i trade-unionistiske forestillinger og organisationsformer, må dette politiske magtspørgsmål rejses igennem og under ledelse af et avangardeparti. 
Denne skitsering af bolsjevikkernes teori og praksis omkring Oktoberrevolutionen skulle have vist, at udviklingen i Sovjetunionen og i de østeuropæiske lande, hvortil den sovjetiske samfundsmodel blev »eksporteret« ved afslutningen af Den anden Verdenskrig, må forstås som en politisk magtovertagelse uden ophævelse af de grundlæggende samfundsmæssige reproduktionsbetingelser: adskillelsen mellem produktion og behov, og at den udvikling må forstås som værende i overensstemmelse med bolsjevikkernes forestillinger om hvad socialisme og kommunisme er. Ganske vist opfattede og opfatter de socialismen som en overgang til en magtfri kommunisme. Men da denne overgang kun kan ske som »frihed gennem tvang «, må man stadig mere end 65 år efter Oktoberrevolutionen indrømme, at man stadig er under overgang til kommunisme.

\section{De nye fordelingsformer}

I det forgående har jeg vist, at bolsjevikkernes teoretiske kritik og praktiske »overvindelse « af kapitalismen ikke indeholdt en afskaffelse af det fremmedbestemte lønarbejde, men kun ændring af tilegnelsesog fordelingsformer gennem afskaffelsen af den private ejendomsret til produktionsmidlerne og fors $\emptyset \mathrm{g}$ på at erstatte varemarkedets regulering med statslig planregulering. Da avantgardepartiet har opnået magten over statsapparatet bliver det nye i tilegnelses- fordelingsforholdene dettes magt over planreguleringen af arbejds- og konsumfordeling. Der er således tale om nye reguleringsformer af relationerne mellem produktionsprocesserne og mellem disse og de individuelle konsumtionsprocesser. For at kunne diskutere hvorledes de kpstyrede samfund skal sættes på begreb, vil jeg i det følgende kort analysere grundtrækkene i de nye fordelings- og reguleringsformer. Hvor disse relationer under privatkapitalismen primært er reguleret gennem vareudvekslingen på markedet - af værdiloven, søges de nu reguleret i overensstemmelse med partistatens planmål. Da der fortsat er tale om en adskillelse mellem produktion og behov, er der ikke tale om en ophævelse af kapitalismens adskillelse af disse, men om en ny regulering af denne adskillelse, hvori behovene søges underlagt planmålene.

Denne nye form for regulering af adskillelsen mellem produktion og behov betyder også en ændring i forhold til privatkapitalismens akkumulationsbetingelser. Medens det her er enkeltkapitalisternes profitjag, der driver akkumulationen frem, så findes der ikke efter ændringen en tilsvarende entydig dynamiseringsfaktor. Som det fremgik af det forangående afsnit, var det centralt i bolsjevikkernes kritik af kapitalismen, at den hæmmer produktivkræfternes udfoldelse. I overensstemmelse hermed sigtede 
politikken efter magtovertagelsen i Sovjetunionen på en hurtig produktivkraftsudvikling. Denne politik kan næppe betegnes som entydig succesfuld, også selvom man fra partistatens side har søgt denne udvikling gennemført gennem både belønnings- og straffeforanstaltninger, hvis yderpunkt er arbejdslejrene. ${ }^{6}$ Afgørende for de $\varnothing$ konomiske ændringer er derfor partistatens planmål og dennes mulighed for at gennemsætte disse. Dette adskiller partistatsbureaukratiet fra driftsherrerne under privatkapitalismen. Medens sidstnævntes funktioner udtrykker gennemsættelsen af øgningstvangen, så er partistatsbureaukratiet selv med til at sætte disse betingelser.

Selvom reguleringen principielt sker ved at enkeltvirksomhederne og konsumenterne handler i overensstemmelse med de centrale planmål, så er der i realiteten ikke tale om et sådant klart hierarki. Hvad angår enkeltvirksomhederne, så besidder de informationer, der er nødvendige for den centrale planmyndighed. Det er derfor ikke blot planordrer, der strømmer igennem de økonomiske ledelsesfunktioner, men også klager over problemer ved udførelsen og krav om kompensationer. Systemet indeholder derfor en kombination af direktiver og forhandling. (M. Rakovski, op. cit. s. 89)

Det er derfor relevant at undersøge, hvilke modsætninger, der kan opstå mellem den centrale planmyndighed, enkeltvirksomheder og forbrugernes behov. Modsætningerne mellem de centrale planmyndigheder og enkeltvirksomhederne opstår i og med, at der ikke er et sammenfald mellem de centrale planmål for produktionen og dennes fordeling og virksomhedernes interesser, som individuelle virksomheder. Denne modsætning betyder at enkeltvirksomhederne opfylder planmålene på en for dem gunstig, men for helheden uhensigtsmæssig måde. Eksempler på disse modsætninger er legio, f.x. tilbøjeligheden til at producere store og ubrugelige redskaber i stedet for mindre og brugbare, fordi man lettest opfylder planmålene på den første måde. Påpegningen af disse modsætninger er helt centralt for H. Ticktins unders øgelser af forholdene i Sovjetunionen. Han mener, at det mest karakteristiske for denne samfundstype er en stadig voksende spildproduktion. Ticktin mener, at den centrale planlægning reelt er ude af stand til at styre enkeltvirksomhederne, idet disse kan omgå de centrale anvisninger til egen fordel. Denne mangel på kontrol fra de centrale planmyndigheder betyder også, at de ikke er i stand til at allokere de

6. Når vi ser bort fra udelukkelse fra arbejde som politisk disciplineringsmiddel gælder der en »ret til arbejde«. I forhold til privatkapitalismen betyder dette, at partistaten har afskrevet sig et væsentligt $\varnothing$ konomisk disciplineringsmiddel: reservearmeens tryk på de beskæftigede. Dette er en betydelig svækkelse i de umiddelbare $\varnothing$ konomiske disciplineringsmidler overfor lønarbejderne. Ticktin betegner dette som arbejdernes negative kontrol over merproduktet. Se diskussionen mellem Brus og Ticktin, Is Market Socialism Possible or Necessary?, i: Critique nr 141981. 
nødvendige ressourcer, hvorfor enkeltvirksomhederne selv må skaffe sig disse gennem direkte forbindelser til andre enkeltvirksomheder. Resultatet af dette er ifølge Ticktin en totalsamfundsmæssig mangel på regulering. (Se H.H. Ticktin m.fl. Planlose Wirtschaft, Hamburg 1981) ${ }^{7}$

Rakovski anfører, at det er en af partiets - som en organisering på tværs af magthierarkiet - centrale opgaver at modvirke den trussel om systemdesintegration, der ligger i modsætningerne mellem centrale interesser og interesserne hos enkeltvirksomhedslederne. (M. Rakovski, op. cit. 92)

For så vidt hele samfundet ikke fungerer som en arbejdslejr med et striks rationeringssystem, har samfundsindividerne selv valgmuligheder mellem de tilbudte jobs og de mulige konsummidler. Økonomien udtrykker således en dobbelthed med produktion efter administrativt fastsatte principper og atomiserede lønarbejdereksistenser. Disse er dels underordnet produktionen gennem omfang af og fordelingsforhold for konsummidler og dels ved efterspørgslen efter forskellige former for arbejdskraft. Denne indordning af de individuelle behov under partistatens planregulering betyder, at der er tale om et »diktatur over behovene«, som man siger indenfor Budapest-skolen. (Se G. Markus, Planning the Crisis: Remarks on the economic system of Soviet-type societies, i: Praxis International vol 1 no 3 1981.) Dette diktatur er dog ikke absolut politisk bestemt, idet det skal underordnes hensynet til den samfundsmæssige reproduktion. Endvidere varierer dets karakter med omfanget af den »anden økonomi« (produktion og forbrug, der ikke umiddelbart registreres i plansystemet), ændringer i reguleringsformerne for forbruget og i formerne for arbejdskraftsanvendelse og afhændelse af denne. ${ }^{8}$

Efter at partistaten fra slutningen af tresserne ændrede planmålene, således at vægten på massekonsum forøgedes, er der sket en opblødning af dette diktatur, men der er fortsat tale om et sådant, idet det kun er for så

7. Denne bog er et oversat udvalg af artikler fra tidsskriftet Critique, der redigeres af Ticktin.

Selvom man nok kan være noget skeptisk overfor Ticktins mere radikale slutninger, så står der dog det tilbage, at adskillelsen og interesseforskellene mellem centralmyndighederne og enkeltvirksomhederne betyder en begrænsning i centralmyndighedernes kontrol over produktion og fordeling. Det er i relation hertil en pointe hos Ticktin, at en evt. forøget markedsregulering ikke nødvendigvis betyder en større frihed for lønarbejderne, men derimod kan give centralmyndighederne nye og mere effektive kontrolmidler i udøvelsen af deres herredømme. (Se Brus/Ticktin, op. cit. ss. 13-16.)

8. Markus skelner mellem tre typer $\varnothing$ konomi, der gør sig gældende. Den første $\varnothing$ konomi er den officielle plan- eller komandoøkonomi. Den anden $\varnothing$ konomi er den private, der mere eller mindre fungerer efter et markeds- og profitprincip. Denne består af privatvirksomheder og kooperativer. De arbejdere, der beskæftiges her, har ofte et andet officielt arbejde og så dette som »måneskinsarbejde «. Den tredie $\varnothing$ konomi er baseret på personnelle, informelle st $\varnothing t$ terelationer. Denne $\emptyset$ konomi er især gældende for forholdet mellem enkeltvirksomheder i den første $\emptyset$ konomi, hvor man gennem sådanne relationer kan imødegå forsyningsvanskeligheder i det centrale system. (G. Markus, op. cit. ss. 253-256) 
vidt partistaten anerkender eller accepterer behovene, at de får mulighed for at blive realiseret.

Imidlertid eksisterer modsætningen mellem enkeltindivid og partistat også i en bredere forstand end i reguleringen af forbruget. Den individuelle lønarbejdereksistens producerer fordringer om personlige, politiske og sociale rettigheder, der står i modsætning til partiets fordring på det samfundsmæssige magtmonopol og individernes underordning under dette.

Jeg har i det forgående skitseret to væsentlige konfliktdimensioner, der opstår i denne samfundstype. Det drejer sig dels om modsætninger mellem de centrale planmyndigheder og enkeltvirksomhedslederne og dels om modsætninger mellem planmyndighederne og enkeltindividerne. Det er ikke afgørende for disse relationers grundlæggende karakter, om de er reguleret monetært eller gennem forskrifter. En overgang til en monetær regulering ændrer ikke nødvendigvis ved de tilgrundliggende magtforhold, men udgør blot en anden - og måske mere effektiv - måde at gennemsætte disse på. ${ }^{9}$

\section{Statskapitalisme eller postkapitalisme?}

I det forgående har jeg kritiseret opfattelsen af de kp-styrede samfund som overgangssamfund; men hvorledes skal man så bestemme denne samfundstype, er der tale om en særlig kapitalistisk form, statskapitalisme ${ }^{10}$ eller er der tale om en samfundstype, der hverken er kapitalistisk, socialistisk eller en overgangsform dem imellem? I det følgende vil jeg se nærmere på en sådan opfattelse, der betegner dem som postkapitalistiske. ${ }^{11}$ I forlængelse af denne diskussion vil jeg se på hvilke forskelle i kritikken som de to forskellige begreber giver anledning til.

9. Jvnf. note 7 .

10. Som det fremgår af W. Olles artikel, Zur Theorie des Statskapitalismus, (i: Prokla nr 11/12 1974) er statskapitalismebegrebet blevet anvendt i mange forskellige betydninger. Det skal derfor præciseres, at betegnelsen i det følgende kun refererer til den venstre- eller rådskommunistiske kritik af de kp-styrede samfund. Denne kritik udvikledes allerede i tilknytning til bolsjevikkernes magtovertagelse i Rusland. Hovedpointerne i denne kritik er dels at Oktober-revolutionen ikke var en proletarisk revolution, men blot var bolsjevikkernes magterobring, og dels at dette ikke kan opfattes som et »forrædderi«, men må ses som udtryk for bolsjevikkernes fordelingsteoretiske socialismeperspektiv, et perspektiv som de delte med socialdemokraterne i Anden Internationele. Da P. Matticks arbejder udg $\emptyset \mathrm{r}$ den teoretisk mest gennemarbejdede position indenfor denne opfattelse, vil jeg i det følgende referere til hans arbejder.

11. Der tænkes her primært på vesttyskerne R. Damus, R. Rotermundt, U. Schmiederer, H. BeckerPanitz, U. Heidt og E. Mangeng, som alle bruger betegnelsen »postkapitalisme«. Selvom Ticktin ikke selv anvender netop dette udtryk, så er hans argumentationer så parallelle med de nævnte vesttyskes at jeg vil behandle ham på linie med disse.

Den nyere østeuropæiske kritik indskriver sig heller ikke i overgangssamfundsforståelsen, hvorfor den havde været relevant at inddrage her. Jeg har refereret til ungarerne Rakovski og Markus. Imidlertid vil jeg ikke her nærmere diskutere deres opfattelse af disse samfundssystemers grundlæggende sociale karakter. 
Rotermundt, Schmiederer og Becker-Panitz mener ikke at man kan betegne disse lande som kapitalistiske. Begrundelsen herfor er, at der kun kan være tale om kapitalisme,

»hvor alt samfundsmæssigt arbejde udføres som privatarbejde, hvorved alle den samfundsmæssige produktions resultater antager varekarakter.« (Rotermundt m.fl., Die Sovjetunion und Europa, Frankfurt 1979 s. 21)

Dette betyder, at også arbejdskraften må have varekarekter. Den kapitalistiske produktionsmådes klasseforhold er derfor betinget af, at varerelationen er blevet den almene samfundsmæssige relation. Til kapitalisme-bestemmelsen hører derfor dels, at »værdiloven« skaber den samfundsmæssige syntese »bag om ryggen« på producenterne og dels at disses forhold til totalarbejdet fremtræder som et samfundsmæssigt forhold mellem ting. (Rotermundt m.fl. 1979 op. cit. s. 21)

Ud fra disse »krav« er det åbenbart, at man ikke kan tale om kapitalisme i den her undersøgte samfundstype. Det er dog problematisk ved Rotermundt m.fl.'s afgrænsning, at de binder bestemmelsen alene til fordelingsformerne - syntesen gennem vareforholdene - og ikke til de forhold, der fremkalder denne form for syntesedannelse, nemlig adskillelsen mellem produktion og behov.

Denne problematik vil jeg fastholde ved nærmere at undersøge postkapitalisme-positionens centrale kritik af statskapitalismeopfattelse. For det første fremføres det, at statskapitalismeopfattelsen suggererer en falsk forståelse af, at der fortsat er tale om en markedsreguleret kapitalistisk produktion med varer, priser og profit. For det andet anføres det, at der slet ikke er tale om lønarbejde i denne samfundstype.

Hvad angår den første indvending påpeger kritikkerne, at pengepriser spiller en helt anden rolle i disse samfund end i de privatkapitalistiske, idet de ikke anvendes som medium til regulering af forholdet mellem produktion og behov, men primært anvendes til formidling af at tvangskonsum, altså kun tjener til realisering af den af planmålene bestemte produktion. (Rotermundt m.fl. 1979, op. cit. s. 35) Priserne angiver derfor ikke det abstrakte arbejdes værdistørrelse, men er derimod i væsentlighed bestemt af partistatens reguleringsinteresser. ${ }^{12}$

Endvidere påpeges det at profitten ikke har samme betydning for akkumulationen som under privatkapitalismen, da produktionen af profit her ikke er den grundlæggende rationalitet, for enkeltvirksomhederne.

12. Dette må betyde at pengepriserne ikke fungerer som værdimål, men kun som prismålestok. Ticktin udtrykker dette noget kryptisk ved at anføre, at pengene kun fungerer som generel ækvivalent og ikke som almen. (H. Ticktin m.fl., op. cit. s. 51). 
Det afgørende orienteringspunkt for disse er derimod »afsætningsvolumer«. (H. Ticktin m.fl. op. cit. s. 38).

Hvad angår den rådskommunistiske statskapitalismeopfattelse så synes disse indvendinger at være fejladresseret. ${ }^{13}$ Man må derfor sige, at lige så rigtige som disse påpegninger er, lige så irrelevante er de, som kritik af Matticks statskapitalismeopfattelse, idet Mattick deler opfattelsen af, at tilstedeværelsen af priser her ikke betyder at systemet er reguleret gennem vareværdiernes konkurrence på markedet:

»Statskapitalisme er stadig et »merværdi« producerende system, men det er ikke længere et system, der finder sin »regulering « gennem markedskonkurrence og krise. Merproduktet kræver ikke længere markedskonkurrence for at kunne realiseres som profit; dets specifikke materielle karakter og dets distribution afledes af bevidste beslutninger fra de statslige planlægningsorganers side. At disse beslutninger også er bestemt af international økonomisk og politisk konkurrence og af akkumulationens krav ændrer ikke det faktum, at manglen på et indre kapitalmarked kræver et centralt bestemt, direkte beslutningssystem med henblik på allokeringen af det samlede samfundsmæssige arbejde og fordelingen af det totale samfundsmæssige produkt.«(P. Mattick, 1973, s. 248-249) $)^{14}$

Der er således taget hensyn til de nye fordelingsformer i Mattick's statskapitalistismeforståelse, hvilket også fremgår af, at han bestemmer det statskapitalistiske system ved at »regeringsbeslutninger og økonomisk planlægning bestemmer produktion, distribution og udvikling.« (P. Mattick, 1973, op.cit. s. 239)

Den anden indvending mod statskapitalismeopfattelsen var, at det under denne samfundstype slet ikke er meningsfuldt at tale om lønarbejde, og hermed om et lønarbejder-kapital forhold. I det følgende vil jeg referere R. Damus' argumentation desangående fra hendes Kursbuch-artikel »Ist die Arbeit im Sozialismus Lohnarbeit?« fra 1974. $)^{15}$

Indledningsvis kritiserer Damus statskapitalismeopfattelsen for at begå den fejl, at reducere lønarbejdet til et aktivitetskendetegn eller en betalingsmåde, og derfor ikke begribe lønarbejdet som et socialt for-

13. For en sådan fejladressering se H. Ticktin m.fl., op. cit. s. 25 note 1.

14. Det skal dog anføres, at Mattick selv er med til at bringe usikkerhed om sin argumentation ved at skrive, at det er et »merværdi«producerende system. Gåseøjnene signalerer nok en ny anvendelse af værdibestemmelsen, men de forklarer den ikke.

15. Benægtelsen af, at man skulle kunne tale om lønarbejde, findes tilsvarende hos R. Rotermundt, m.fl. op cit. s. 28, men ikke hos Heidt/Mangeng. Ticktin imødegår ikke direkte opfattelsen af, at der eksisterer fremmedbestemt $1 \emptyset$ narbejde. Derimod argumenterer han for at arbejdskraften ikke er en vare, da der ikke eksisterer noget egentligt arbejdskraftsmarked. (H. Ticktin m.fl., op. cit. ss 48-52). 
hold. (R. Damus, op. cit. s. 92) Herudfra mener hun ikke, at man kan tale om lønarbejde under »postkapitalismen«. Som afsætning for denne argumentation fastslås det, at det som karakteriserer kapitalismen er, at det samfundsmæssigt enhedsstiftende princip ligger i bytteforholdene. Disse udgør de indirekte forbindende bånd mellem de formelt frie og lige samfundsmedlemmer. Denne form for samfundsmæssig syntese betyder, at herredømmeforholdene bliver middelbare - formidlet over byttet.

Et ikke-kapitalistisk samfund er derfor rent logisk bestemt ved negationen af syntese-dannelsen gennem bytteforholdene. Denne negation kan enten føre til ophævelse af herredømmet, og hermed til etableringen af »konkrete samfundsmæssigg ørelsesformer « eller til nye herredømmeformer, hvis karakter er umiddelbar. Hvad angår de her behandlede postkapitalistiske samfund, så skabes den samfundsmæssige syntese gennem planøkonomi. Selvom der ikke her er tale om »konkret samfundsmæssiggørelse «, så er der dog tale om en negering af byttet som samfundsmæssig syntese, og hermed af kapitalismen. Damus' begrundelse for, at der ikke er tale om »konkret samfundsmæssiggørelse«, men om nye umiddelbare herredømmeformer baseres på, at der i planlægningen anvendes traditionelle ansporingsmidler. Derfor er planen udtryk og middel for nye herredømmeforhold. (R. Damus, op. cit. s. 93-99)

Da plansystemets herredømme er direkte, begrænser det sig ikke kun til bytteprocessen. Hermed ophæves den tilsyneladende, faktiske delvise selvstændighed mellem de samfundsmæssige delområder. De bliver alle underlagt den politiske vilje.

»Heraf følger, at der ikke kan tales om lønarbejde; det kan der ikke fordi den direkte samfundsmæssige syntese, der gennemsættes via den umiddelbare og dermed politiske herredømmeudøvelse, ikke blot udøves overfor arbejdskraften hos varebesiddere, der som sådan er formelt frie og lige individer. Herredømmet reproduceres nemlig ikke over den middelbare sociale tvang til at sælge arbejdskraften, men langt snarere rådes der direkte over individerne i deres helhed.« (R. Damus, 1974, op. cit. s. 100-101, cit fra s. 101.)

Damus' afvisning, af at tale om lønarbejde under postkapitalismen, er altså baseret på, at hun begrænser det kapitalismekarakteristiske til samfundssyntesen gennem varebyttet, hvorved kapitalherredømmet reduceres til det indirekte herredømme i vareudvekslingen. Dette betyder at hun i sin kapitalismebestemmelse slet ikke indreflekterer denne synteses forudsætning: produktionens adskillelse fra producenternes behov. 
Derfor reflekteres driftsherrens herredømme i produktionen ikke som kapitalismebestemt. Ej heller får hun begrebet det politiske herredømme over privatejerne som moment i det kapitalistiske herredømme. For så vidt disse direkte herredømmeformer også begribes som momenter i det kapitalistiske herredømme, kan de privatkapitalistiske samfund ikke adskilles fra de "postkapitalistiske « ud fra Damus' distinktion indirekte/ direkte herredømme. ${ }^{16}$

Selvom partistaten griber ind overfor alle lønarbejdernes livsforhold, ændrer det ikke ved det grundlæggende forhold, at den enkelte arbejder, for at kunne reproducere sig, må stille sin arbejdskraft til rådighed, hvor den kan afsættes. Hermed argumenterer jeg kun for, at lønarbejderbegrebet ikke er meningsløst; men jeg har ikke dermed påstået, at lønarbejdet - som under privatkapitalismen - har varekarakter under disse forhold. Prisen på arbejdskraft bliver ikke primært fastsat gennem markedskonkurrencen, der er omfattende restriktioner i arbejdsmarkedsmobiliteten og endelig spiller selve den udbetalte løn kun en begrænset rolle for den enkeltes reproduktionsmuligheder. (Se H.H. Ticktin m.fl. op. cit. s. 48-52)

Det er altså kun ved at reducere det kapitalismebestemmende til udvekslingsforholdene, at Damus kan benægte tilstedeværelsen af lønarbejde under »postkapitalismen«. Betegnelsen »postkapitalisme« bliver problematisk, hvis man derimod fastholder et kapitalismebegreb, der tager udgangspunkt i produktionsbetingelserne. Det er det Mattick gør, når han påpeger, at kapitalisten grundlæggende ikke er karakteriseret ved ejendom til produktionsmidlerne, men som »konsument af arbejdskraft«. (P. Mattick, op. cit. s. 258) Da dette fremmedbestemte herredømme over producenten ikke ændres med de nye samfundsmæssigg ørelsesformer, mener Mattick, at det er berettiget at fastholde kapitalismebestemmelsen også for disse samfund. Det nye er blot, at produktionsmidlerne i stedet for at være ejet af privatkapitalister nu er ejet og kontrolleret af staten, privatkapitalisterne er blevet erstattet af en statskapitalist. Denne ændring er selvfølgelig ubehagelig for de tidligere privatkapitalister, men for lønarbejderne gælder det stadig, at de er underlagt et fremmedherredømme i produktionsprocessen. (P. Mattick, Marxism - Yesterday, Today, and Tomorrow, i: Root and Branch nr 10, 1981 s. 24.)

16. Det utilstrækkelige i denne distinktion fremgår også af hendes forsøg på at eksemplificere, at der i postkapitalismen til forskel fra i kapitalismen eksisterer et direkte herredømme over arbejderen, idet der her bliver disponeret over ham fra vugge til grav. De eksempler som hun fremfører på dette - f.x. reguleringen af individernes udfoldelsesmuligheder gennem tilladelse til bestemte uddannelsesmuligheder - adskiller sig ikke principielt fra den statslige regulering der er kendt i de kapitalistiske velfærdslande. (R. Damus, op. cit. s. 101). 
Lønarbejdet eksisterer fortsat som formidler af adskillelsen mellem produktion og behov, og hermed gælder også lønarbejdets »dobbelte frihed «: udelukkelsen fra direkte rådighed over produktionsmidlerne og retten til selv at afhænde sin arbejdskraft. Kun for så vidt der er tale om en helt igennem tvangsmæssig allokering af arbejdskraften, kan man tale om lønarbejdets afskaffelse.

Man kan indvende imod Matticks kapitalismebestemmelse, at den modsat binder kapitalismebestemmelsen ensidigt til produktionsrelationerne - kapitalisten som konsument af arbejdskraft. Dette åbner for en udvidelse af kapitalismebestemmelsen til at gælde for alle tvangsregulerede samfund med adskillelse mellem produktion og behov, og hermed negligere værdireguleringens centrale betydning for kapitalismebestemmelsen. Uden at ville konkludere definitivt, mener jeg, at der her ligger en væsentlig problematisering af statskapitalismeforståelsen. Dog skal det i relation hertil påpeges, at der også i de privatkapitalistiske lande sker en betydelig politisk bestemt fordeling af produktionen, så også her sker fordelingen ikke udelukkende gennem værdilovens fordeling »bag om ryggen «.

Som afslutning på diskussionen af statskapitalismebegrebet overfor postkapitalismebegrebet, mener jeg at kunne fastslå, at kritikken af statskapitalismeopfattelsen henholder sig til en kapitalismeforståelse, der begrænser sig til fordelingsformerne, og derved ikke medreflekterer de samfundsmæssige forudsætninger for disse. Dette gælder såvel Damus, Rotermundt m.fl. som Ticktin. Selvom Heit og Mangeng også anvender postkapitalismetermen, har de ikke samme reducerede kapitalismeforståelse som de lige nævnte. En mulig forklaring på, at repræsentanter for postkapitalismeopfattelsen generelt insisterer på, at de nye samfundsmæssiggørelsesformer er uforenelige med kapitalisme, kan være deres baggrund i den tyske rekonstruktionslitteratur, hvori det er en central påpegning, at »værdiloven « ikke blot er en beregningsmåde, men en reelt fungerende samfundsmæssig reguleringsmekanisme. Værdireguleringen gennem udvekslingen bliver derfor det helt centrale for begribelse af den kapitalistiske reproduktionsform.

Kritikken af postkapitalismeopfattelsen har primært sigtet på dens reduktion af det kapitalismekarakteristiske til fordelingsforholdene, medens statskapitalismebestemmelsen er blevet fremhævet for at fastholde denne forudsætning: adskillelsen af produktion og behov. Men hvad betyder egentlig denne forskel for undersøgelsen af samfundene. Jeg mener, at det vigtige i forskellen er, at statskapitalismebestemmelsen fastholder et kapitalisme-kritisk perspektiv både overfor udviklingen i øst og vest. 
Hvad angår det første, så åbner statskapitalismeopfattelsen op for en forståelse af de sociale modsætninger, der udvikles i disse samfund. Når det grundlæggende samfundsmæssige forhold her er et kapitallønarbejder-forhold, betyder det, at der også udvikles krav til lønarbejdereksistensen f.x. ytringsfrihed, ret til selvstændig faglig organisering, ret til frit valg af arbejde og politiske krav om frie valg. Disse krav, der udspringer af lønarbejdereksistensens interesser, er i modsætning til partistatens fordring på politisk beslutningsmonopol. Dermed opstår der legitimeringsproblemer for det herskende styre. Dette implicerer en ideologisk modsætning i systemet: på den ene side produceres og reproduceres der eksistensbetingelser, der rejser krav om personlige, politiske og sociale rettigheder, og på den anden side må disse krav undertrykkes, da de er uforenelige med det eksisterende partiherredømme. Dette kan enten ske ved åben tvang eller ved opbygning af nye legitimitetsmønstre: som ved benægtelse af tilstedeværelse af emancipatoriske potentialer i den »konkurrence« kapitalisme (at fremstille den som tendentielt barbari), ved at bruge krigsfrygten til at skaffe opbakning om styret, eller ved forsikring om, at undertrykkelsen af befolkningsgrupper kun er temporær og nødvendig for en fremtidig frihed. Der er således tale om den paradoksale situation, at borgerlige rettigheder bliver til kritikpotentialer i samfundssystemer, der påstås at befinde sig på et højere »udviklingsniveau«. Men dette har selvfølgelig den »fordel«, at magthaverne kan stemple kritikken som kontrarevolutionær etc. Tilsvarende opfattes disse krav ofte kapitalismeapologetisk i de privatkapitalistiske lande, nemlig som krav om tilbagevenden til kapitalistiske produktionsforhold.

Pointen ved statskapitalismebegrebet er altså, at man fastholder, at kapitalismens modsætninger også genskabes i de krav som opposionelle og reformbevægelser fremfører. Som eksempel herpå kan nævnes, at Solidarnosc foruden at kræve retten til frie og uafhængige fagforeninger også - for at komme det ineffektive statslige bureaukrati til livs - rejste krav om markedsregulering af priserne, og om at virksomhedernes udvikling skulle reguleres gennem indbyrdes konkurrence. (Se: Opg $\varnothing$ ret med den autoritære socialisme, København 1982) Både indenfor en overgangs- og postkapitalisme-forståelse kan sådanne krav kun forstås som et $\varnothing$ nske om tilbagevenden til kapitalismen. Jeg vil derfor hævde, at disse opfattelser blokerer for en forståelse af oppositions- og reformbevægelser i disse samfund, idet de ikke bestemmes som udtryk for modsætningerne i disse landes reproduktionsformer.

Den anden centrale pointe ved statskapitalismebegrebet er, at det fastholder en kritik af den kapitalistiske arbejderbevægelses socialismefor- 
ståelse. For Mattick er det en central pointe, at opfattelsen af socialisme som afskaffelse af privatejendom og markedets anarki er gældende både indenfor den socialdemokratiske og den partikommunistiske arbejderbevægelse, hvorfor hans kritik af disse ikke går på, at de har forrådt deres idealer, men at de idemæssigt er bundet af de kapitalistiske reproduktionsformer. (P. Mattick, Capitalism and Socialism, i: Root and Branch nr 10, 1981 ss. 17-19)

Dette udelukker dog ikke, at der er væsentlige forskelle dem imellem. Det er der, men denne forskel går på forholdet til det politiske demokrati. Medens socialdemokraterne opfatter det politiske demokrati som en gennemkæmpet rettighed i det borgerlige samfund - det der mangler er, at demokratiet ikke også omfatter økonomien - så opfatter partikommunisterne det politiske demokrati i det borgerlige samfund primært som et skærmbræt for borgerskabets reelle politiske magt. ${ }^{17}$

17. Som den østrigske socialdemokrat O. Bauer allerede påpegede i 1920, så skyldes socialdemokraternes kritik af forholdene i USSR ikke, at landet er socialistisk, men at det også er despotisk: »Det (USSR (m.a.)) er et socialistisk samfund, som er opstået. Thi sovjetmagten har fravristet kapitalisterne arbejdsmidlerne, befriet arbejdsprocessen fra kapitalens herredømme, frataget kapitalisterne rådigheden over arbejdsresultatet og organiserer nu selv ... en planmæssig, umiddelbar, samfundsmæssig fordeling af arbejdsresultatet. Men når det er socialisme, så er det dog en socialisme af særlig karakter, en despotisk socialisme.«(O. Bauer, Bolschewismus oder Sozialdemokratie?, Wien 1920 s. 62 f, her cit. fra W. Olle, op. cit. s. 133.) 